\title{
Dampak Pendidikan Kewirausahaan Terhadap Niat Wirausaha Mahasiswa dengan Pendekatan Model TPB
}

\author{
Femmy Effendy*1, Dudi Awalludin ${ }^{2}$, Ratih Huriyati ${ }^{3}$, Disman Disman ${ }^{4}$, Mokh. Adib Sultan ${ }^{5}$, Sukma \\ Nugraha $^{6}$, Suhono Suhono ${ }^{7}$. \\ ${ }^{1,2}$ Program Studi Sistem Informasi, STMIK ROSMA, Karawang \\ 2,3,4,5,6,7 Sekolah Pascasarjana Universitas Pendidikan Indonesia \\ ${ }^{1}$ Jl. Kertabumi No.62, Karawang Kulon, Kec. Karawang Bar., Kabupaten Karawang, Jawa Barat 41311 \\ 2 Jl. Dr. Setiabudhi No.229, Cidadap, Isola, Sukasari, Isola, Kec. Sukasari, Kota Bandung, Jawa Barat 40154 \\ *femmy@rosma.ac.id
}

\begin{abstract}
This study is to see the impact of entrepreneurship education provided through entrepreneurship courses on entrepreneurial intentions among students in Karawang-West Java. The research model was adopted from Theory Planned Behavior (TPB). The theory of planned behavior includes independent variables, namely attitudes, subjective norms, and behavioral control. While the dependent variable, entrepreneurial intention is used. Questionnaires were distributed via google form to students who have taken entrepreneurship courses, as many as 115 samples were obtained, and 100 samples that met the criteria were used for processing. Research analysis using SEM PLS found that subjective norms and behavioral control did not affect the intention to entrepreneurship, only attitude that had a significant effect on the intention to entrepreneurship in students. These results prove in the sample taken that the attitude of students more causes entrepreneurial intention, how they are interested in seeing business opportunities, have a positive view of things and always dare to take any risks that come. This finding is expected to change the education plan for entrepreneurship courses, which are expected to include elements to increase interest, think positively, and be optimistic to generate intentions to become an entrepreneur.
\end{abstract}

Keywords : Entrepreneurship Education; Entrepreneurship Intention; University Student; Theory Planned Behavior (TPB.

\begin{abstract}
Abstrak - Penelitian ini untuk melihat dampak pendidikan kewirausahaan yang diberikan melalui mata kuliah kewirausahaan terhadap niat wirausaha di kalangan mahasiswa di kota Karawang-Jawa Barat. Model penelitian diadopsi dari Theory Planned Behavior (TPB). Aplikasi theory of planned behavior yang meliputi variabel bebas yaitu sikap, norma subyektif dan kontrol perilaku. Sedamngkan variabel terikat, digunakan niat berwirausaha. Kuesioner disebar melalui google form kepada mahasiswa yang sudah menempuh mata kuliah kewirausahaan, sebanyak 115 sample didapatkan, dan digunakan 100 sampel yang memenuhi kriteria untuk diolah. Analisis Penelitian dengan menggunakan SEM PLS, ditemukan bahwa norma subjective dan kontrol perilaku tidak mempengaruhi niat untuk berwirausaha, hanya sikap yang berpengaruh signifikan terhadap niat untuk berwirausaha pada mahasiswa. Hasil ini membuktikan pada sampel yang diambil bahwa niat wirausaha lebih disebabkan pada sikap dari mahasiswa , bagaimana mereka tertarik untuk melihat adanya peluang usaha, berpandangan positif terhadap sesuatu dan selalu berani mengambil resiko apapun yang datang. Temuan ini diharapkan dapat merubah rencana pendidikan mata kuliah kewirausahaan yang diharapkan juga dapat memasukkan unsur untuk meningkatkan rasa tertarik, berfikir secara positif dan bersikap optimis yang dapat membangkitkan niat untuk menjadi seorang wirausaha.
\end{abstract}

Kata Kunci : Pendidikan Kewirausahaan; Niat Wirausaha; Mahasiswa, Theory Planned Behavior (TPB).

\section{PENDAHULUAN}

Tingkat Kewirausahaan di Indonesia masih lebih rendah jika dibandingkan negara-negara di Asia Tenggara dengan ratio hanya di angka 3,47\% dari total populasi penduduk sebagaimana data yang dilaporkan dari Badan Pusat Statistik [1] Sebagai perbandingan ratio kewirausaahaan di Singapura mencapai 9\% bahkan Thailand dan Malaysia diangka 5\%. Jumlah penduduk Indonesia sampai Desember 2020 mencapai 272 juta jiwa. [2], yang artinya paling sedikit jumlah wirausaha ada pada angka 38 juta jiwa diharapkan dapat menjadi wirausahawan. Hal ini adalah salah satu indikator syarat untuk menjadi negara maju dimana jumlah wirausaha harus lebih dari $14 \%$ dari jumlah penduduknya

Kementrian Koperasi Usaha Kecil dan menengah mengembangkan program wirausaha muda pada tahun 2021 dalam upaya meningkatkan rasio kewirausahaan. Berbagai cara dilakukan seperti dengan menyediakan pendampingan bisnis dan layanan konsultasi bisnis di lingkungan perguruan tinggi, hal ini sebagai usaha untuk dapat menjaring minat dan bakat wirausaha di kalangan mahasiswa. [3]. Pengklasifikasian kelompok umur penduduk Indoensia oleh William H Frey menunjukkan bahwa kelompok usia produktif yang didominasi oleh generasi milenial, sebagaimana terlihat pada gambar 1. Generasi milenial yag lahir di

Business Innovation and Entrepreneurship Journal (BIEJ) is published under licensed of a CC BY-SA Creative Commons Attribution-ShareAlike 4.0 International License. e-ISSN : 2684-8945

DOI : 10.35899/biej.v3i3.316 
tahun 1981-1996 sejumlah 25.87\% dari total jumlah penduduk.

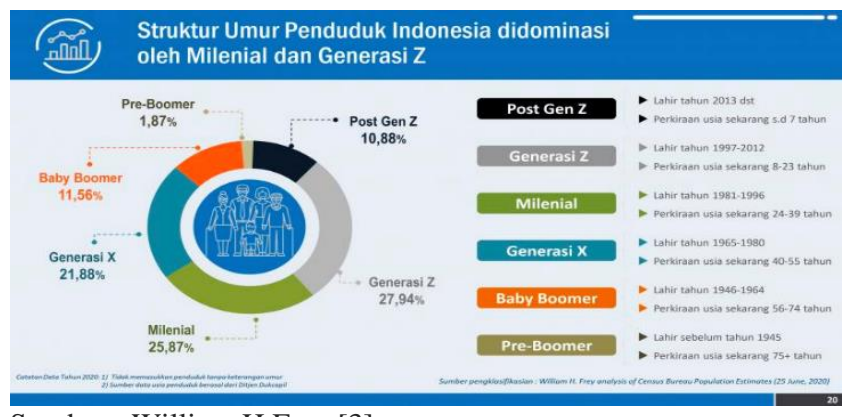

Sumber : William H Frey [3]

Gambar 1. Struktur penduduk Indonesia

Milenial saat ini memegang kendali terhadap roda perekonomian bangsa, sehingga upaya untuk menguatkan potensi wirausaha muda yang berkualitas menjadi suatu hal yang harus menjadi perhatian pemerintah. Perguruan tinggi yang memiliki sumber daya manusia yang berkualitas dalam jumlah besar sangat layak menjadi sumber penguatan dan pengembangan wirausaha produktif. Beberapa milenial dari berbagai latar belakang profesi muncul dengan karya-karya kreatif dan inovatif. Profesi baru atau jenis usaha baru yang dulu belum ada seperti mendirikan Start Up, Web Designer, Content Creator, Bussines Analyst, Media Planner, Youtuber dan lain sebagainya berkembang sangat pesat saat ini. Dan semua ini merupakan bentuk-bentuk usaha yang dilakukan para millenial untuk mencapai kesuksesan. Keterkaitan antara pendidikan, dan niat wirausaha sebenarnya telah lama menjadi subjek penelitian internasional yang komprehensif. Sebagai contoh, beberapa penelitian, terutama pada awal abad ini, menunjukkan meningkatnya peran pendidikan, terutama pendidikan tinggi. [4]-[6].

Penelitian yang dilakukan oleh Nurul Indarti [7] menyatakan bahwa mahasiswa Indonesia sedikit lebih menyukai menjadi entrepreneur daripada bekerja di perusahaan yang artinya ada kecenderungan para mahasiswa untuk tertarik menjadi seorang wirausaha. Perbandingan gender juga memiliki pengaruh terhadap niat wirausaha pada penelitian yang dilakukan oleh Nowonski dkk, meskipun wanita umumnya memiliki niat kewirausahaan yang lebih rendah dan menunjukkan tingkat pendidikan kewirausahaan yang lebih rendah, ternyata justru mereka mendapat manfaat lebih banyak daripada pria dari pendidikan kewirausahaan [8]. Adanya hubungan positif antara pendidikan kewirausahaan dan niat dan keinginan umtuk melakukan wirausaha [9]. Beberapa penelitian terkait hubungan antara adanya pembelajaran kewirausahaan dan niat wirausaha juga dilakukan beberapa peneliti berikut [5]-[7], [10]-[13]. Pendekatan dengan menggunakan model theory planned behavior digunakan pada penelitian untuk melihat sejauh mana sikap, norma subyektif dan kontrol perilaku berpengaruh terhadap niat wirausaha pada mahasiswa yang sudah menempuh mata kuliah kewirausahaan. Mengingat pentingnya pembelajaran kewirausahaan maka untuk meningkatkan niat mahasiswa untuk menjadi seorang wirausaha maka diperlukan reformasi sistem pendidikan untuk mendorong kreativitas dan inovasi siswa.

\section{KAJIAN PUSTAKA}

\section{Kewirausahaan/Entrepreneurship}

Kewirausahaan adalah tindakan menciptakan, membangun dan meningkatkan bisnis untuk menghasilkan keuntungan [8]. Definisi kewirausahaan yang lebih modern juga tentang mengubah dunia dengan memecahkan masalah besar. Seperti memulai perubahan sosial menciptakan produk inovatif atau menghadirkan solusi baru yang mengubah hidup [14]. Kewirausahaan atau Entrepreneurship adalah suatu proses yang bersifat kreatif dan inovatif dan sesuatu yang dianggap baru dan memberikan nilai. Entrepreneurship berasal dari bahasa prancis yaitu entereprende yang berarti petualang, pencipta, dan pengelola usaha. Istilah ini dikemukan pertama kali oleh Rihard Cantillon [15]. Coulter dalam bukunya yang berjudul "Entrepereneurship in Action" menyebutkan kewirausahaan adalah kaitan antara proses pembentukan dan pertumbuhan suatu bisnis yang orientasinya adalah untuk mendapatkan keuntungan, menciptakan nilai , produk atau jasa baru yang unik dan inovatif.

\section{Niat Wirausaha/Entrepreneurship Intention}

Entrepreneurship Intention adalah keadaan pikiran yang dapat mengarahkan atau membimbing individu untuk bertindak menuju pengembangan dan implementasi konsep bisnis baru [16]. Niat untuk melakukan perilaku tertentu dibentuk dan dipengaruhi oleh berbagai faktor, seperti kebutuhan, nilai, keinginan, kebiasaan, dan keyakinan [17] dan ditambah dengan faktor situasional [18]. Niat adalah penilaian subjektif tentang bagaimana seseorang akan bertindak untuk melakukan sesuatu di masa depan, dan. Sedangkan wirausahawan adalah individu yang bertujuan untuk menjadi wiraswasta dan merupakan 
cara bagi mereka untuk mencapai kesuksesan pribadi mereka [13].

\section{Pendidikan Kewirausahaan / Entrepreneurship Education}

Pendidikan kewirausahaan mengacu pada silabus atau mata kuliah yang memaparkan siswa dengan kemampuan kewirausahaan, pengetahuan dan keterampilan [14]. Sifat kewirausahaan tidak dapat diprediksi, penuh risiko dan tantangan [15], penelitian yang dilakukan oleh sarjana sebelumnya menunjukkan bahwa ini adalah alasan utama yang mengurangi niat wirausaha mahasiswa, terutama bagi individu yang kurang memiliki perilaku berisiko terhadap. Pendidikan kewirausahaan telah dilihat oleh para peneliti sebelumnya sebagai platform pelatihan formal yang mempersiapkan sarjana untuk menjelajahi dunia kewirausahaan. Pendidikan kewirausahaan memaparkan mahasiswa pada proses pengembangan bisnis, pengetahuan dan keterampilan manajemen bisnis, seperti manajemen sumber daya manusia, manajemen keuangan, manajemen risiko, serta proses pengambilan keputusan yang kompleks [16]. Alhasil, sarjana dipersiapkan untuk menghadapi risiko dan tantangan yang potensial dihadapi dalam dunia wirausaha. Studi yang dilakukan oleh peneliti sebelumnya juga menyarankan bahwa pendidikan kewirausahaan merupakan salah satu faktor penentu yang paling penting untuk menciptakan keinginan siswa terhadap kewirausahaan dan mengarah ke kewirausahaan [17].

\section{Mahasiswa}

Mahasiswa didefinisikan seseorang yang sedang dalam proses menimba ilmu ataupun belajar dan terdaftar sedang menjalani pendidikan pada salah satu bentuk perguruan tinggi yang terdiri dari akademik, politeknik, sekolah tinggi, institut dan universitas. Mahasiswa secara harfiah adalah orang yang belajar di perguruan tinggi, baik di universitas, institut atau akademi. Mereka yang terdaftar sebagai murid di perguruan tinggi otomatis dapat disebut sebagai mahasiswa [18]. Mahasiswa adalah seorang yang sudah lulus dari Sekolah Lanjutan Tingkat Atas (SLTA) dan sedang menempuh pendidikan tinggi [19]. Mahasiswa menerima lebih banyak pendidikan di bidang kewirausahaan [5]. [8] Hasilnya menunjukkan dampak pendidikan dan efikasi diri kewirausahaan pada niat kewirausahaan positif dan signifikan di negara, Polandia. Adanya hubungan antara tingkat pendidikan dan pembelajaraan woirausaha terhadap niat wirausaha di kalangan mahasiswa.

\section{Theory Planned Behavior (TPB)}

Peran dalam pembentukan Entrepreneurship Intention pada berbagai penelitian didasarkan, pertama-tama, pada TPB yang memberikan landasan teoritis yang kuat [14]. Perilaku akan masa depan seseorang didahului oleh niat, dianggap semakin kuat niat seseorang untuk terlibat dalam perilaku tertentu, semakin besar kemungkinan perilaku yang sebenarnya akan dilakukan. Lebih lanjut, niat untuk melakukan suatu perilaku tertentu merupakan hasil dari tiga anteseden kognitif: (i) sikap terhadap perilaku; (ii) norma subjektif; dan (iii) kontrol perilaku yang dirasakan. TPB didasarkan pada gagasan bahwa manusia agak rasional dalam pilihan mereka dan niat individu mengarah atau tidak mengarah pada perilaku tertentu [6]. TPB tidak membedakan antara keyakinan tentang hasil yang orang pilih untuk dikejar karena kemauan dan diri sejati, dan keyakinan tentang hasil yang dipaksa untuk dicapai karena kewajiban [4]. Hasil analisis bibliometric juga menunjukkan bahwa TBP adalah model yang banyak digunakan untuk mengukur niat wirausaha mahasiswa [20]. Sementara ada sejumlah studi tentang niat kewirausahaan yang menerapkan TPB kepada mahasiswa [4]-[7]. Temuan menunjukkan hubungan positif antara pendidikan kewirausahaan dan niat dan keinginan yang dirasakan sementara tidak ada hubungan dengan kelayakan yang dirasakan atau self-efficacy [9]. Pendidikan kewirausahaan memberikan siswa pengalaman berbagai teknis dan keterampilan untuk menjadi lebih percaya diri sebagai seorang wirausaha. Selain pendidikan, motivasi, kepribadian dan latar belakang keluarga juga menentukan niat berwirausaha. [11] [14]. Kebutuhan psikologis dasar otonomi, kompetensi dan keterkaitan memiliki dampak tidak langsung yang kuat pada niat kewirausahaan melalui anteseden sikap mereka: sikap, norma subjektif, dan kontrol perilaku yang dirasakan. [16]-[19]. [21]-[30] Theory of Planned Behavior tidak dapat dipisahkan dari niat berwirausaha, karena dalam teori ini dikemukakan bahwa pembentukan perilaku wirausahawan didasarkan pada keyakinan dan evaluasi untuk menumbuhkan sikap (attitude against), norma 
subjektif, dan kontrol perilaku yang dirasakan. Penelitian ini menguji pengaruh Theory of Planned Behavior terhadap niat berwirausaha dan juga menggunakan faktor demografi untuk melihat apakah ada perbedaan niat berwirausaha berdasarkan jenis kelamin, pengalaman kerja, pengalaman pelatihan kewirausahaan dan pekerjaan orang tua Berdasarkan latar belakang penelitian dan sumber dari beberapa penelitian terdahulu maka, peenelitian ini mengadopsi model Theory Planned Behavior, yang dapat kami gambarkan sebagai berikut:

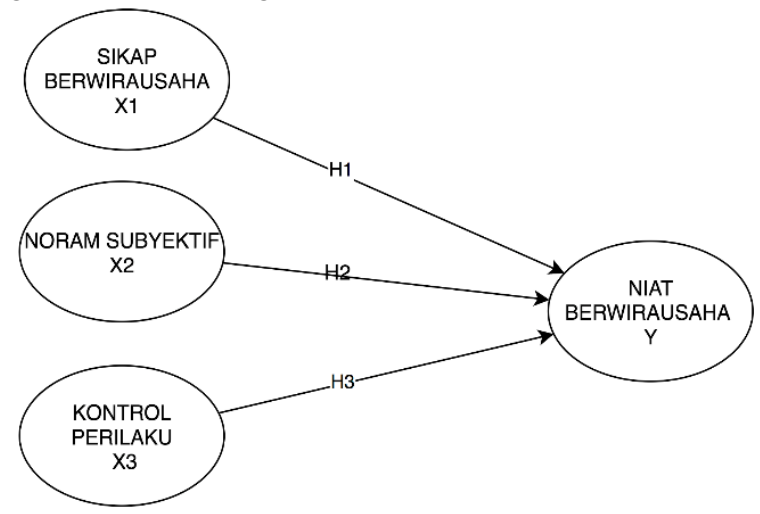

Gambar 2. Model Penelitian

Hipotesis penelitian

H1 : Sikap diduga berpengaruh signifikan terhadap niat berwirausaha.

H2 : Norma Subyektif diduga berpengaruh signifikan terhadap niat berwirausaha

H3 : Kontrol Perilaku diduga berpengaruh signifikan terhadap niat berwirausaha

\section{METODE PENELITIAN}

Metode penelian dilakukan dengan pendekatan kuantitaf yaitu penelitian dengan menggunakan metode ilmiah yang sistematis terhadap bagian-bagian fenomena serta terdapat kausalitas antar variabelnya. Lokasi penelitian bertempat di Kota Karawang, Jawa Barat. Subjek yang akan diteliti merupakan mahasiswa pada Perguruan Tinggi yang ada di kota Karawang yang sudah menempuh mata kuliah kewirausahaan. Objek penelitian ini adalah variabel bebas yang terdiri dari Sikap (X1), Norma Subyektif (X2), Kontrol Perilaku (X3) dan dengan variable terikat Niat Berwirausaha (Y). Berdasarkan waktunya, penelitian ini adalah cross sectional method, yaitu waktu pengambilan sampel satu kali saja pada saat yang sama. Pengambilan sampel di bulan Maret-Mei 2021. Penelitian ini menggunakan non probability sampling, adalah teknik pengambilan sampel yang anggota populasinya tidak mempunyai peluang yang sama. Dan metode purposive sampling yang merupakan salah satu teknik sampling non probabillity, dimana peneliti menentukan pengambilan sampel dengan cara menetapkan ciri-ciri khusus yang sesuai dengan tujuan penelitian sehingga diharapkan dapat menjawab permasalahan penelitian. Total jumlah sampel yang diteliti diambil sebanyak 100 dari 115 sampel yang didapatkan. Pengumpulan data dilakukan dengan menyebarkan daftar pernyataan melalui google form kepada responden untuk mendapatkan tanggapan atas pernyataan yang diajukan. Pengukuran menggunakan skala likert antara satu sampai lima, di mana skala likert digunakan untuk mengukur variabel sikap (X1), norma subyektif (X2), kontrol perilaku (X3) dan niat berwirausaha (Y). Alat analisis yang digunakan dalam penelitian ini, adalah dengan menggunakan software SEM PLS.

\section{HASIL DAN PEMBAHASAN}

\section{Karakteristik Responden}

Responden yang didapatkan dari waktu penyebaran kuesioner yang dimulai dari maret 2021Mei 2021 dalam penelitian ini sebanyak 115 mahasiswa, namun hanya 100 responden yang bisa diolah untuk dianalis. Responden semua berasal dari beberapa perguruan tinggi di kota Karawang. Karakteristik responden dapat dilihat pada tabel 1 dibawah ini

\begin{tabular}{lr}
\multicolumn{2}{c}{ Tabel 1. Karakteristik Responden } \\
\hline Jenis kelamin & Jumlah \\
\hline Laki-Laki & 33 \\
Perempuan & 67 \\
Nama Perguruan Tinggi & 71 \\
\hline Universitas Singaperbangsa Karawang & 27 \\
STMIK Rosma & \\
Universitas Nahdatul Ulama Cirebon & 2 \\
Kampus IV Karawang
\end{tabular}

Data yang didapatkan dari tiga perguruan tinggi yang ada di kota Karawang, dengan jumlah respoden terbanyak berasal adari Universitas Singaperbangsa yang merupakan satu-satunya universitas negeri di kota Karawang dan dengan jumlah mahasiswa terbanyak. Mahasiswa Laki-laki 33 dan mahasiswa perempuan 67 orang yang mengisi kueisiener yang disebarkan. 


\section{Uji Validitas dan Reliabilitas}

Karena pengukuran dalam penelitian ini dimodifikasi dan/atau dipersempit dari penelitian sebelumnya, validitas dan reliabilitas diuji. Ambang batas yang dapat diterima untuk cut of value reliability (CR) adalah > 0,7 dan untuk average variance extract $(\mathrm{AVE})>0,5$. Selain itu, ambang batas minimum untuk Cronbach adalah 0,5 atau 0,6, sehingga ambang batas untuk alfa Cronbach dalam penelitian ini adalah >0,6. Pada Tabel 1. Menunjukkan nilai cronbach alpha > 0,05 , sehingga semua instrumen penelitian dianggap valid dan nilai composite reliability $>0,7$ semuanya dianggap reliabel. Hasil uji validitas dan reliabilitas bisa dilihat pada tabel 2:

Tabel 2. Uji Validitas dan Reliabilitas

\begin{tabular}{|c|c|c|c|c|c|c|}
\hline & 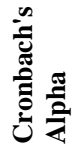 & $\begin{array}{l}4 \\
\stackrel{1}{!}\end{array}$ & 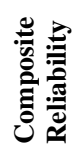 & 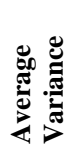 & لَّ & $\cong$ \\
\hline $\begin{array}{l}\text { Sikap } \\
\text { berwirausaha } \\
\text { (X1) }\end{array}$ & 0,761 & $\begin{array}{r}0,80 \\
6\end{array}$ & $\begin{array}{r}0,86 \\
0\end{array}$ & $\begin{array}{r}0,67 \\
3\end{array}$ & $\begin{array}{l}0.747- \\
0.873\end{array}$ & NA \\
\hline $\begin{array}{l}\text { Norma } \\
\text { subjekti (X2) }\end{array}$ & 0,662 & $\begin{array}{r}0,70 \\
3\end{array}$ & $\begin{array}{r}0,81 \\
4\end{array}$ & $\begin{array}{r}0,59 \\
6\end{array}$ & $\begin{array}{l}0.692- \\
0.730\end{array}$ & NA \\
\hline $\begin{array}{l}\text { Kontrol } \\
\text { perilaku (X3) }\end{array}$ & 0,699 & $\begin{array}{r}0,72 \\
3\end{array}$ & $\begin{array}{r}0,83 \\
0\end{array}$ & $\begin{array}{r}0,62 \\
1\end{array}$ & $\begin{array}{l}0.764- \\
0.856\end{array}$ & NA \\
\hline $\begin{array}{l}\text { Niat } \\
\text { berwirausaha } \\
\text { (Y) }\end{array}$ & 0,730 & $\begin{array}{r}0,78 \\
3\end{array}$ & $\begin{array}{r}0,84 \\
9\end{array}$ & $\begin{array}{r}0,65 \\
9\end{array}$ & $\begin{array}{l}0.614- \\
0.902\end{array}$ & $\begin{array}{c}0.5 \\
2\end{array}$ \\
\hline
\end{tabular}

Sumber : SEM PLS , data diolah 2021

Tabel 3. Loading Faktor Indikator

\begin{tabular}{|c|c|c|c|c|}
\hline & 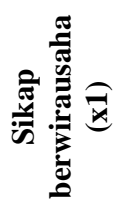 & 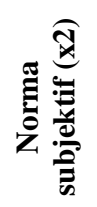 & 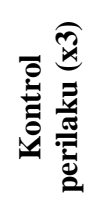 & 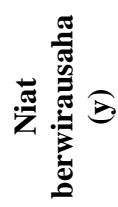 \\
\hline $\mathrm{X} 11$ & 0,873 & & & \\
\hline $\mathrm{X} 12$ & 0,836 & & & \\
\hline $\mathrm{X} 13$ & 0,747 & & & \\
\hline $\mathrm{X} 21$ & & 0,730 & & \\
\hline $\mathrm{X} 22$ & & 0,880 & & \\
\hline X23 & & 0,692 & & \\
\hline X31 & & & 0,856 & \\
\hline X32 & & & 0,739 & \\
\hline X33 & & & 0,764 & \\
\hline Y11 & & & & 0,902 \\
\hline Y12 & & & & 0,886 \\
\hline y13 & & & & 0,614 \\
\hline
\end{tabular}

Validitas Diskriminan

Validitas Diskriminan; pada tabel 4 menunjukkan validitas diskriminan antara konstruk yang digunakan. Karena nilai diagonal lebih besar dari nilai terkait lainnya, konstruk menunjukkan validitas diskriminan yang dapat diterima. Validitas diskriminan mengacu pada tingkat perbedaan antara atribut yang seharusnya tidak diukur oleh alat ukur dan konsep teoritis tentang variabel. Validitas diskriminan juga dapat dihitung dengan membandingkan akar kuadrat dari nilai rata-rata varians diekstraksi (AVE). Jika nilai AVE lebih besar dari nilai korelasi antar variabel laten, maka validitas diskriminan dapat dianggap tercapai. Validitas diskriminan dapat dikatakan tercapai jika nilai AVE lebih besar dari 0,5.

Tabel 4. Validitas Diskriminan

\begin{tabular}{l}
\hline \\
Kontrol perilaku (x3) \\
Niat berwirausaha (y)
\end{tabular}

\section{Uji Hipotesis}

Untuk menguji hipotesis yang diajukan, model partial partial squares (PLS) dianalisis untuk memverifikasi hipotesis penelitian. Hasil uji hipotesis diilustrasikan pada Tabel $5, \mathrm{P}<0,05$ (berpengaruh dan signifikan).

Tabel 5. Hasil Uji Hipotesis

\begin{tabular}{|c|c|c|c|c|c|}
\hline & 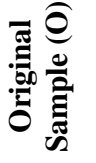 & 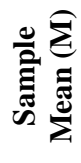 & 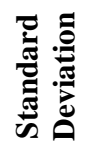 & 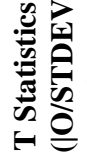 & $\frac{\mathscr{E}}{ٍ}$ \\
\hline $\begin{array}{l}\text { Kontrol perilaku -> } \\
\text { niat berwirausaha }\end{array}$ & 0,335 & 0,324 & 0,185 & 1,811 & 0,071 \\
\hline $\begin{array}{l}\text { Norma subjektif -> } \\
\text { niat berwirausaha }\end{array}$ & 0,039 & 0,059 & 0,146 & 0,266 & 0,790 \\
\hline $\begin{array}{l}\text { Sikap } \\
\text { berwirausaha (x1) } \\
\text {-> niat } \\
\text { berwirausaha }\end{array}$ & 0,283 & 0,302 & 0,142 & 1,987 & 0,047 \\
\hline
\end{tabular}




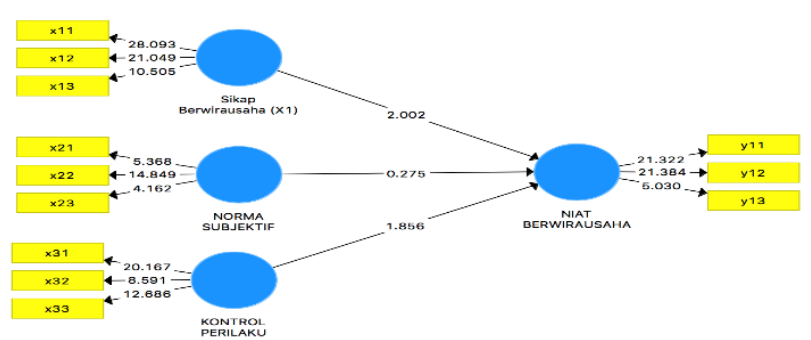

Gambar 3. Model Penelitian dengan Nilai T Statistik

Dari tabel 5 , dapat kita lihat bahwa hipotesis pertama yang menyatakan bahwa H1 : Sikap Berwirausaha berpengaruh positif dan signifikan terhadap niat mahasiswa dalam berwirausaha terbukti, hasil pengolahan data menunjukan nilai $p$ value sebesar $0.047<0.05$. Hal ini sejalan dengan penelitian yang dilakukan oleh [5] Sikap pro-kewirausahaan dalam semua kasus berhubungan positif dengan niat wirausaha, sikap yang dapat mempengaruhi perilaku dalam berwirausaha [11][12]. Sikap untuk tertarik kepada suatu peluang baru, berani mencoba, berfikir positif menjadi indikator bagaimana mahasiswa berniat untuk mencoba wirausaha. Diharapkan unsur-unsur yang dapat membangkitkan sikap seperti ini bisa dimasukkan ke dalam capaian pembelajaran pada mata kuliah kewirausahaan. Hipotesis kedua bahwa H2 : Norma Subjektif berpengaruh positif dan signifikan terhadap niat mahasiswa dalam berwirausaha tidak terbukti pada penelitian ini. Indikator keyakinan peran keluarga, dukungan dalam usaha dari orang yang dianggap penting dan dukungan dari teman tidak dianggap dapat memicu keinginan untuk wirausaha. Dianggap faktor dari pengaruh orang-orang terdekat bukan menjadi suatu permasalahan dalam niat untuk berwirausaha. Walaupun lingkungan sosial cukup mendukung, namun keyakinan untuk memulai suatu usaha belum dapat dimunculkan. Hasil penelitian ini tidak sejalan dengan hasil yang menyatakan bahwa norma subyektif berpengaruh positif dan signifikan terhadap niat wirausaha [4]. Hasil yang berbeda ini dimungkinkan karena faktor kultur masyarakat yang berbeda antara mahasiswa yang berdomisili di kota Karawang dan mahasiswa di Malaysia. Hipotes ketiga bahwa H3 : Kontrol Perilaku berpengaruh positif dan signifikan terhadap niat mahasiswa dalam berwirausaha juga tidak terbukti pada penelitian ini walaupun mahasiswa merasa percaya diri akan kemampuan mengelola usaha, memiliki jiwa kepemimpinan dan mampu berfikir kreatif masih belum terbukti dapat membangkitkan niat wirausaha, hal ini berbeda dengan hasil penelitian [5] yang menemukan bahwa ada hubungan yang signifikan antara cara berfikir kreatif dengan niat berwirausaha.
Selain itu penelitian ini juga untuk melihat indikator mana yang paling mempengaruhi niat wirausaha yang membentuk variabel Sikap (X1). Hasil loading faktor pada indikator X11 adalah penilaian bahwa "Saya selalu tertarik untuk memanfaatkan peluang atau usaha baru" dengan nilai loading faktor 0.873 memiliki angka tertinggi dibandingkan kedua nilai loading faktor yang lainnya. Hal ini dapat disimpulkan ada indikasi bahwa mahasiswa yang memiliki sikap untuk merasa tertarik tentang sesuatu hal yang baru diyakini juga tertarik dan memiliki niat untuk menjalankan suatu bisnis. Sikap yang mengarah kepada niat utuk berwirausaha dimulai dari rasa ketertarikan. Seseorang mempunyai niat terhadap sesuatu maka perhatiannya akan sendirinya tertarik pada objek tersebut. Pernyataan "tertarik untuk memanfaatkan dengan peluang usaha baru" dinilai oleh sebagian besar mahasiswa sebagai nilai lebih yang dapat menunjang niat berwirausaha. Untuk indikator terkuat kedua yaitu "Saya berpandangan positif terhadap kegagalan usaha yang saya alami dengan nilai loading faktor 0.836 . Mahasiswa berpandangan positif terhadap kegagalan akan dengan mudah untuk berniat menjalankan suatu usaha. Dan Indikator terakhir dari variabel sikap adalah pernyataan "Saya selalu berani mengambi resiko apapun yang datang" dengan nilai loading faktor 0.747. Mahasiswa yang berani mengambil resiko adalah mahasiswa yang nantinya tertarik untuk menjalankan suatu usaha yang berawal dari niat untuk berwirausaha. Nilai $R$ square sebesar 0.52 juga mengindikasikan bahwa masih terdapat faktor faktor lain yang berpengaruh terhadap niat berwirausaha selain ketiga variabel yang diteliti.

\section{KESIMPULAN DAN SARAN}

Hasil dari penelitian pengujian hipotesis dengan SEM PLS ditemukan pengaruh sikap berwirausaha, secara positif dan signifikan terhadap niat berwirausaha mahasiswa sedangkan norma subyektif dan kontrol perilaku tidak terbukti berpengaruh signifikan terhadap niat berwirausaha mahasiswa di kota Karawang. Sikap berwirausaha dengan indikator rasa ketertarikan merupakan kunci utama yang mendorong mahasiswa untuk berniat terjun ke dunia usaha. Daya tarik atau kekuatan yang menarik dari sesuatu memunculkan minat atau niat. Ketertarikan pada suatu hal atau aktivitas menimbulkan niat perilaku. Menyikapi hal ini maka sudah saatnya mata kuliah kewirausahan di design untuk dapat menciptakan rasa tertarik dari mahasiswa untuk 
berwirausaha. Dengan menggabungkan antara teori dan praktek ataupun memberikan bimbingan dan arahan kepada mahasiswa dengan merancang proses pembelajaran merancang suatu model bisnis yang ide dasarnya dari mahasiswa mungkin bisa menjadi salah satu terobosan yang bisa dilakukan. Penelitian ini memiliki keterbatasan dimana tidak semua mahasiswa masuk kedalam sampel penelitian dan sebaran juga hanya pada tiga perguruan tinggi, hasil berbeda mungkin dapat ditemukan pada sebaran sample yang lebih merata. Penelitian masih dalam cakupan yang sempit hanya pada mahasiswa di kota karawang dengan hanya terdiri dari tiga variabel penelitian. Diharapkan penelitian berikutnya dapat menggunakan model teori selain TPB dan dengan cakupan yang lebih luas sehingga hasil yang didapatkan lebih komprehensif.

\section{REFERENSI}

[1] Badan Pusat Statistik, "Laju Pertumbuhan Penduduk (Persen), 2021," www.bps.go.id, 2021.

https://www.bps.go.id/indicator/12/1976/1/laju -pertumbuhan-penduduk.html (accessed Jun. 02, 2021).

[2] Badan Pusat Statistik, "Hasil Sensus Penduduk 2020," www.bps.go.id, 2020. .

[3] U. Indonesia, "Pemilihan Wirausaha Muda dan Penggerak Wirausaha Berprestasi," ukmindonesia.id, 2019.

[4] I. Al-Jubari, A. Hassan, and F. Liñán, "Entrepreneurial intention among University students in Malaysia: integrating selfdetermination theory and the theory of planned behavior," Int. Entrep. Manag. J., vol. 15, no. 4, pp. 1323-1342, 2019, doi: 10.1007/s11365018-0529-0.

[5] D. Maresch, R. Harms, N. Kailer, and B. Wimmer-Wurm, "The impact of entrepreneurship education on the entrepreneurial intention of students in science and engineering versus business studies university programs," Technol. Forecast. Soc. Change, vol. 104, pp. 172-179, 2016, doi: 10.1016/j.techfore.2015.11.006.

[6] M. Küttim, M. Kallaste, U. Venesaar, and A. Kiis, "Entrepreneurship Education at University Level and Students' Entrepreneurial Intentions," Procedia - Soc. Behav. Sci., vol. 110, pp. 658-668, 2014, doi: 10.1016/j.sbspro.2013.12.910.

[7] N. Indarti, "Factors Affecting Entrepreneurial
Intentions Among Indonesian Students," Factors Affect. Entrep. Intentions Among Indones. Students, vol. 19, no. 1, pp. 57-70, 2015, doi: 10.22146/jieb.6585.

[8] W. Nowiński, M. Y. Haddoud, D. Lančarič, D. Egerová, and C. Czeglédi, "The impact of entrepreneurship education, entrepreneurial self-efficacy and gender on entrepreneurial intentions of university students in the Visegrad countries," Stud. High. Educ., vol. 44, no. 2, pp. 361-379, 2019, doi: 10.1080/03075079.2017.1365359.

[9] H. W. Hattab, "Impact of Entrepreneurship Education on Entrepreneurial Intentions of University Students in Egypt," J. Entrep., vol. 23, no. 1, pp. 1-18, 2014, doi: $10.1177 / 0971355713513346$.

[10] V. Barba-Sánchez and C. Atienza-Sahuquillo, "Entrepreneurial intention among engineering students: The role of entrepreneurship education," Eur. Res. Manag. Bus. Econ., vol. 24, no. 1, pp. 53-61, 2018, doi: 10.1016/j.iedeen.2017.04.001.

[11] R. K. Jena, "Measuring the impact of business management Student's attitude towards entrepreneurship education on entrepreneurial intention: A case study," Comput. Human Behav., vol. 107, no. December 2018, p. 106275, 2020, doi: 10.1016/j.chb.2020.106275.

[12] Z. Y. Ren, P. Li, and Y. X. Li, "The relationship between entrepreneurial self-efficacy and entrepreneurial intention," Int. Conf. Manag. Sci. Eng. - Annu. Conf. Proc., vol. 2018-Augus, pp. 517-522, 2018, doi: 10.1109/ICMSE.2018.8744855.

[13] K. Amofah, R. Saladrigues, and E. K. AkwaaSekyi, "Entrepreneurial intentions among MBA students," Cogent Bus. Manag., vol. 7, no. $1, \quad$ pp. $0-23, \quad 2020$, doi: 10.1080/23311975.2020.1832401.

[14] G. Genoveva, "the Influence of Entrepreneurial Culture on Entrepreneurial Intention Among Business Students," Firm J. Manag. Stud., vol. 4, no. 1, p. 40, 2019, doi: 10.33021/firm.v4i1.682.

[15] F. F. Budi, "Pengaruh Pendidikan Kewirausahaan Dalam Menumbuhkan Minat Berwirausaha," J. Pengabdi. dan Kewirausahaan, vol. 2, no. 1, p. 7, 2018, [Online]. Available: http://finance.detik.com/berita-ekonomi- 
bisnis/d-.

[16] B. Bird, "Implementing Entrepreneurial Ideas: The Case for Intention," Acad. Manag. Rev., vol. 13, no. 3, p. 442, 1988, doi: $10.2307 / 258091$.

[17] S. H. Lee and P. K. Wong, "An exploratory study of technopreneurial intentions: A career anchor perspective," J. Bus. Ventur., vol. 19, no. 1, pp. 7-28, 2004, doi: 10.1016/S08839026(02)00112-X.

[18] F. Liñán, "Intention-based models of entrepreneurship education," Piccola Impresa / Small Bus., vol. 2004, no. 3, pp. 11-35, 2004.

[19] T. O. Kowang, S. Z. B. A. Apandi, O. C. Hee, G. C. Fei, M. S. I. Saadon, and M. R. Othman, "Undergraduates entrepreneurial intention: Holistic determinants matter," Int. J. Eval. Res. Educ., vol. 10, no. 1, pp. 57-64, 2021, doi: 10.11591/ijere.v10i1.20733.

[20] D. Awalludin, F. Effendy, R. Hurriyati, D. Disman, and M. Adib, "Study of Entrepreneurial Intentions Among University Students : Bibliometrics Analysis," 2021.

[21] E. Deri, I. Santika, and I. Giantari, "Niat Berwirausaha Dikalangan Mahasiswa (Studi:Mahasiswa Program Reguler Fakultas Ekonomi Dan Bisnis Universitas Udayana)," None, vol. 5, no. 2, p. 246607, 2016.

[22] Y. Chrismardani, "Theory Of Planned Behavior Sebagai Prediktor Intensi Berwirausaha," Kompetensi Vol.10 No.1, vol. 28, no. 3, pp. 550-562, 2016, [Online]. Available:

http://www.dbpia.co.kr/Article/3031618.

[23] A. W. Wijayanti and G. A. Putri, "Model Theory of Planned Behavior (TPB) untuk Memprediksi Niat Mahasiswa Melakukan Kecurangan Akademik," J. Manaj. dan Kewirausahaan, vol. 14, no. 2, pp. 189-197, 2016.

[24] J. C. Sánchez, "University training for entrepreneurial competencies: Its impact on intention of venture creation," Int. Entrep. Manag. J., vol. 7, no. 2, pp. 239-254, 2011, doi: 10.1007/s11365-010-0156-X.

[25] G. Nabi, R. Holden, and A. Walmsley, "Entrepreneurial intentions among students: Towards a re-focused research agenda," $J$. Small Bus. Enterp. Dev., vol. 17, no. 4, pp. 537551, 2010, doi: 10.1108/14626001011088714.

[26] M. Radzi et al., "Entrepreneurial Intention Among University Students.," Am. J. Bus.
Educ., vol. 8, no. 4, pp. 1-9, 2013.

[27] S. N. A. Ambad and D. H. D. A. Damit, "Determinants of Entrepreneurial Intention Among Undergraduate Students in Malaysia," Procedia Econ. Financ., vol. 37, no. 16, pp. 108-114, 2016, doi: 10.1016/s22125671(16)30100-9.

[28] D. Purwana, "Determinant Factors of Students' Entrepreneurial Intention: a Comparative Study," Din. Pendidik., vol. 13, no. 1, pp. 1-13, 2018, doi: 10.15294/dp.v13i1.12971.

[29] F. Liñán, D. Urbano, and M. Guerrero, Regional variations in entrepreneurial cognitions: Start-up intentions of university students in Spain, vol. 23, no. 3-4. 2011.

[30] P. Zhang, D. D. Wang, and C. L. Owen, "A study of entrepreneurial intention of university students," Entrep. Res. J., vol. 5, no. 1, pp. 6182, 2015, doi: 10.1515/erj-2014-0004.

$\underline{\text { Business Innovation and Entrepreneurship Journal (BIEJ) is published under licensed of a CC BY-SA Creative Commons }}$ Attribution-ShareAlike 4.0 International License. 